\title{
Urates in exhaled breath condensate of children with obstructive sleep apnea
}

\author{
Vukmir Vlasic ${ }^{1}$, Jasenka Trifunovic ${ }^{2}$, Ivana Cepelak ${ }^{3}$, Petra Nimac', Renata Zrinski Topic ${ }^{5}$, Slavica Dodig ${ }^{5 *}$ \\ ${ }^{1}$ Women's \& Children's Hospital, Pediatric Pulmonology, Lafayette, LA, USA \\ ${ }^{2}$ Clinical Hospital Center Osijek, Department of Clinical Biochemistry, Osijek, Croatia \\ ${ }^{3}$ Faculty of Pharmacy and Biochemistry, Department of Medical Biochemistry and Hematology, University of Zagreb, Zagreb, Croatia \\ ${ }^{4}$ Srebrnjak Children's Hospital, Pediatric Department, Zagreb, Croatia \\ ${ }^{5}$ Srebrnjak Children's Hospital, Department of Clinical Laboratory Diagnosis, Zagreb \\ *Corresponding author: slavica@dodig.net
}

\section{Abstract}

Background: Urate levels may be a marker of oxidative stress. The aim of the present study was to find out are there any differences in urate concentrations in exhaled breath condensate (EBC) between children with obstructive sleep apnea (OSA) and healthy children.

Materials and methods: EBC was collected in children with obstructive sleep apnea (OSA) and clinically healthy children. Urate measurements in $E B C$ and serum were performed by enzymatic color test.

Results: The higher concentration of urates in $\mathrm{EBC}$ of children with OSA than clinically healthy children indicate the oxidative stress in their airways. Since there was no significant difference in serum concentration of urates between children with OSA and healthy children, it could be considered that urates are sintetized in the airways of children with OSA.

Conclusions: The present study indicated that urates in EBC (but not in serum) may be used as a marker of local synthesis of antioxidant compoun$\mathrm{ds}$, but definitive conclusion must be supported by investigations involving larger number of participants.

Accepted: March 24, 2011

\section{Introduction}

Obstructive sleep apnea, OSA, is disorder characterized by repeated episodes of apnea and hypopnea during sleep. It is a common disorder in pediatric population, affecting 2 to $3 \%$ of all children (1). OSA is related to increased upper airway resistance. The majority of children with OSA have miId-to-moderate symptoms (2). Frequently OSA is associated with the presence of adenotonsillar hypertrophy, septal deviation or macroglosia $(3,4)$. Usually, snoring is the first sign of sleep disordered breathing that leads parents to consult a clinician. In adult patients with OSA, nasal and oropharingeal mucosal inflammation are confirmed. Recurrent episodes of airway obstruction are associated with decreased partial pressure of oxygen and decreased oxygen hemoglobin saturation during sleep, and finally with hypoxia and tissue damage.
Oxidative stress, inflammation and vascular remodeling are basic mechanisms associated with OSA (5). Inflammation cascade depend upon intermittent hypoxia. Oxidative stress is characterized by impaired balance between formation of reactive oxygen species (ROS) and intra- and extracellular antioxidant species (6).

Polysomnography is the gold standard for diagnosing sleep-disordered breathing. As oxidative stress and inflammation are the basic mechanisms in OSA (5), determination of both, local and systemic, biomarkers of oxidative stress and inflammation in patients with OSA, becomes a challenge to biomedical scientists.

Urate, as a strong reducing agent, electron donor and antioxidant, binds prooxidant metals, i.e. iron and copper, thus preventing their interaction with 
$\mathrm{H}_{2} \mathrm{O}_{2}$ to produce hydroxyl radical (7). It reacts with ROS, and inhibits lipid peroxidation (6). In addition, it was confirmed that urates may stabilize another powerful antioxidant, ascorbic acid (8). Increased plasma urate concentration may be a marker of oxidative stress (9).

The aim of this cross-sectional and comparative study was to find out are there any difference in urate concentrations in exhaled breath condensate $(E B C)$ between children with OSA and healthy children. It was hypothesized that oxidative stress might influence the changes in EBC urate concentration in children with OSA in comparison to healthy children. To the best of our knowledge, it is the first study of EBC urate concentrations in patients with OSA.

\section{Materials and methods}

\section{Study subjects}

A cross-sectional case series of consecutive, otherwise healthy children aged 5-12 years were included in the study. Children were divided into two groups: Group 1, children with OSA ( $=17$ ). Inclusion criteria were the presence of habitual snoring, reported by parents. In addition, clinically healthy children, without snoring, as volunteers, were also included (Group 2, $N=12$ ). Exclusion criteria included the presence of syndromic abnormalities, acute upper respiratory tract infection and use of antibiotics or inhaled corticosteroids in the last four weeks. Diagnostic work-up was performed according to standardized procedure (in line with ethical principles and Declaration on Human Rights from Helsinki 1975 and Seoul amendments 2008., and a written informed consent was obtained from the parents. The study was approved by the Hospital Ethics Committee. Eligible subjects were individually selected by the principal investigator (VV).

\section{Methods}

Polisomnography was done in the sleep laboratory of the pediatric department at Srebrnjak Children's Hospital. Polysmith ${ }^{\text {TM }}$ polysomnographic recording and Polysmith $^{\text {тM }}$ Data Management
Solutions Scheduler and Database (Nihon Kohden $\mathrm{GmbH}$, Rosbach, Germany), were used according to American Thoracic Society guidelines (10). The severity of OSA was expressed by apnea-hypopnea index $(\mathrm{AHI})$. $\mathrm{AHI}$ is calculated by dividing the number of hypopneas and apneas by the number of hours of sleep.

Forced expiratory volume in one second (FEV1) was measured using a spirometar Jaeger MS BB/ IOS system (Jaeger, Würzburg, Germany), and presented as percentage of predicted values (reference values $>80 \%$ of predicted).

Fractional concentration of exhaled $\mathrm{NO}\left(\mathrm{F}_{\mathrm{E}} \mathrm{NO}\right)$, at exhaled air flow rate of $50 \mathrm{~mL} / \mathrm{s}$, was measured using a NIOXs Nitric Oxide Monitoring System chemiluminiscence analyzer (Aerocrine AB, Stockholm, Sweden), reference intervals for children up to 12 years: 5-15 ppb.

Blood sampling was performed according to standardized procedures. The concentration of high sensitivity C-reactive protein, hsCRP (immunoturbidimetric method on latex particles, reference values $<2.8 \mathrm{mg} / \mathrm{L}$ ) and urates (enzymatic color test with uricase, reference intervals in children $<7$ years: $105-295 \mu \mathrm{mol} / \mathrm{L}$; in children 8 to 12 years: 125-228 $\mu \mathrm{mol} / \mathrm{L})$ were determined on Beckman Coulter AU 400 biochemistry analyzer (Beckman Coulter Tokyo, Japan), using Beckman Coulter Diagnostics, Hamburg, Germany).

EBC samples were collected according to the ATS/ ERS Task Force recommendation (11) using an EcoScreen condenser (Erich Jaeger $\mathrm{GmbH}$, Hoechberg, Germany). Urates measurements were performed about 10-15 minutes after EBC collection by the same method as in serum samples. Detection limit for urate concentrations was $5 \mu \mathrm{mol} / \mathrm{L}$ (own validation data). The assay repeatability/reproducibility studies using Bland and Altman plots yielded satisfactory results. The intra-assay coefficients of variation for the values of $10 \mu \mathrm{mol} / \mathrm{L}, 50$ $\mu \mathrm{mol} / \mathrm{L}$ and $100 \mu \mathrm{mol} / \mathrm{L}$ were $3.8 \%, 2.3 \%$ and $1.8 \%$, respectively.

\section{Statistical analysis}

On data processing, MedCalc software (Version 10, Medisoftware Mariakerke, Belgium) was used. The 
variables were described by median (M) and interquartile range (IQR). In addition, the age was expressed by median, and minimal/maximal values, respectively. As small samples were tested, rank sum tests, i.e. Mann-Whitney test and Wilcoxon test, were used for comparison of independent and paired variables, respectively. Correlation of the study variables was expressed by Spearman's coefficient of rank correlation. The values $P$ $<0.05$ were considered statistically significant (12).

\section{Results}

\section{Antropometric data, polisomnography, lung function}

The children enrolled in the study were matched by age ( $P=0.877)$, i.e. the children in Group 1 were aged 5 to 12 years [8 (7-11)], and children in Group
2 were at age from 6 to 12 years [9 (7-11)]. There was no statistically significant difference in BMI between Group 1 [10.67 (16.32-19.16) kg/m²] and Group 2 [17.67 (15.97-21.26) kg/m²], P = 1.000 (Table 1). The median AHI values for the Group 1 were statistically higher [3.54 (1.13-8.07)] than in control group of children $[0.59(0.54-1.47)]$, respectively ( $P=$ 0.026). In four children from Group 2 patients, $\mathrm{AHI}$ value exceeded 1.15, and in other eight children $\mathrm{AHI}$ value was less than 1, i.e. less than normal values as reported by Marcus et al (13).

There was no statistically significant difference in FEV1 between Group 1 [90.5 (86.0-101.5) \% of predicted] and Group 2 [94 (88.2-102.3) \% of predicted], $P=0.554$. In addition, there was no statistically significant difference $(P=0.079)$ in $F_{E} N O$ between Group 1 [12.65 (10.0-19.95) ppb], and Group 2 [9.5 (6.88-16.48) ppb].

TABLE 1. The main characteristics of children with OSA (Group 1) and the control group of children (Group 2)

\begin{tabular}{|c|c|c|c|}
\hline Parameter & $\begin{array}{l}\text { Group } 1 \\
\mathbf{N}=17\end{array}$ & $\begin{array}{l}\text { Group } 2 \\
\mathbf{N}=12\end{array}$ & $\mathbf{P}$ \\
\hline Age (years) & $8(7-11)$ & $9(7-11)$ & 0.877 \\
\hline BMI $\left(\mathrm{kg} / \mathrm{m}^{2}\right)$ & 10.67 (16.32-19.16) & $17.67(15.97-21.26)$ & 1.000 \\
\hline $\mathrm{AHI}(1)$ & $3.54(1.13-8.07)$ & $0.59(0.54-1.47)$ & 0.026 \\
\hline FEV1 (\% of predicted) & 90.5 (86.0-101.5) & $94(88.2-102.3)$ & 0.554 \\
\hline FENO (ppb) & 12.65 (10.0-19.95) & $9.5(6.88-16.48)$ & 0.079 \\
\hline $\mathrm{hsCRP}(\mathrm{mg} / \mathrm{L})$ & $1.21(0.41-1.99)$ & $0.26(0.23-0.97)$ & 0.045 \\
\hline Urates serum ( $\mu \mathrm{mol} / \mathrm{L})$ & $255(220-277)$ & $194(182-236)$ & 0.060 \\
\hline EBC - volume (mL) & $1.5(1.0-1.7)$ & $2.2(1.6-2.9)$ & 0.030 \\
\hline Urates EBC ( $\mu \mathrm{mol} / \mathrm{L})$ & $86(28-113)$ & $31(23-42)$ & 0.046 \\
\hline \multicolumn{4}{|c|}{$\begin{array}{l}\text { Data are presented with median (interquartile range). } \\
\text { BMI - body mass index; AHI - apnea-hypopnea index; FEV1 - forced expiratory volume in one second; hsCRP - high sensitive } \\
\text { C-reactive protein; EBC - exhaled breath condensate }\end{array}$} \\
\hline
\end{tabular}

\section{Biomarkers}

The concentrations of hsCRP (Table 1) in Groups 1 and 2 were $1.21(0.41-1.99) \mathrm{mg} / \mathrm{L}$, and $0.26(0.23-$ $0.97) \mathrm{mg} / \mathrm{L}$, respectively. The difference was statistically significant, $P=0.045$. There was no statistically significant difference in serum urates in Group 1 [255 (220-277) $\mu \mathrm{mol} / \mathrm{L}]$ in comparison with Group 2 [194 (182-236) $\mu \mathrm{mol} / \mathrm{L}], \mathrm{P}=0.060$.
In Group 1 patients the volume of collected EBC was 1.5 (1.0-1.7) $\mathrm{mL}$, and in Group 2 subjects the volume was significantly higher $2.2(1.6-2.9) \mathrm{mL}, \mathrm{P}$ $=0.030$. The median value of EBC urates was higher in Group 1 [86 (28-113) $\mu \mathrm{mol} / \mathrm{L}]$ than in Group 2 [31 (23-42) $\mu \mathrm{mol} / \mathrm{L}]$, yielding a statistically significant difference $(P=0.046)$. 
Difference in concentrations of urates between serum and EBC was statistically significant in both, Group $1(P<0.001)$ and Group $2(P=0.001)$ subjects.

Correlation between $\mathrm{AHI}$ and $\mathrm{EBC}$ urate was not recorded neither in Group 1 patients $(r=-0.21$; $P=$ $0.407)$, nor in controls $(r=-0.03 ; P=0.931)$. Negative correlation between serum and EBC urate was only recorded in control group of children $(r=-0.63$; $P=0.046)$, but not in children with OSA $(r=0.01$; $P$ $=0.977$ ).

The median concentration of urates in EBC (86 $\mu \mathrm{mol} / \mathrm{L}$ ) of Group 1 children was 3 times lower than concentration of urates in serum $(255 \mu \mathrm{mol} / \mathrm{L})$. In addition, the concentration of urates in EBC (31 $\mu \mathrm{mol} / \mathrm{L}$ ) in Group 2 children, was 6 times lower than concentration of urates in serum (194 $\mu \mathrm{mol} / \mathrm{L})$.

\section{Discussion}

The higher concentration of urates in EBC of children with OSA than clinically healthy children in the present study, indicate the oxidative stress in their airways. As hsCRP may be considered as a biomarker of chronic latent inflammation $(14,15)$ the latent systemic inflammation may be confirmed in patient with OSA in the present study. Since there was no significant difference in serum concentration of urates between children with OSA and healthy children, it could be considered that urates are sintetized in the airways of children with OSA.

Investigations of Van der Vliet et al. have suggested that concentration of urates in the upper airways is lower than in plasma (16). Our investigation has shown that urates are lower in EBC than in serum of both, children with OSA and clinically healthy children. However, it should be taken in consideration the fact that $\mathrm{EBC}$ is extreme dilute solution $(\sim 1: 20,000)$ of respiratory extracellular lining fluid (RELF) (17) - it means that the in vivo concentration of urates in RELF is significantly higher than in serum. In addition, it means that uric acid is sintetized locally in the airways, as it was confirmed in the investigations on cell cultures (18). The fact that EBC urates (but not serum urates) in children with OSA were higher than in clinically heal- thy children additionally confirms local synthesis of uric acid in the airways. In our previous investigation elevated concentration of urates in EBC of children with controlled asthma [63 (38-111) $\mu \mathrm{mol} / \mathrm{L}]$ was found (19). EBC concentration of urates was unmeasurable (i.e. $<5 \mu \mathrm{mol} / \mathrm{L}$ ) in some children with acute exacerbation of asthma in that study, possibly suggesting that in these patients $E B C$ 's were obtained at the time of enhanced urate consumption due to acute oxidative stress.

EBC was easily collected in children aged over 5 years, suggesting that this noninvasive procedure may provide a useful method for assessment of oxidative stress in the lower airways in the pediatric population. Significant difference was found in the volume of EBC, i.e. in children with OSA smaller volume was collected. Further investigation is needed to explain this difference.

Antioxidant concentration has already been measured in nasal lavage fluid or BAL (16). Uric acid appears to be the main antioxidant in nasal airway secretions. Studies on cell cultures have shown that respiratory tract epithelial cells may also be involved in the synthesis of urates by purine metabolism (18). It seems that an increase of urate concentration follows (20) the initial urate depletion (21), confirming local synthesis of uric acid. To our knowledge, besides our investigation (19) there are no studies that have investigated uric acid, as a marker of oxidative stress, in EBC. Also, we have found only two studies by Goldbart et al. (22) and Li et al. (23) regarding EBC in children and adults, respectively, with OSA. Therefore interpretation of the results presented in this study is very difficult. As the origin of EBC constituents has not been identified (24), the exact anatomical site of origin of urates remains unknown.

In adults with OSA, many EBC biomarkers of inflammation $(\mathrm{pH}, \mathrm{IL}-6)$ and oxidative stress (nitrates, $\mathrm{H}_{2} \mathrm{O}_{2}$, 8-isoprostane, leukotriene $\mathrm{B}$ ) have been found increased (25). In children, concentrations of 8-isoprostane and IL-6 in EBC were found to correlate with clinical score of OSA (26).

In children, elevated serum hsCRP, as a biomarker of inflammation, was confirmed also in patients with asthma and rhinitis $(14,27)$. The present study 
demonstrated that latent systemic inflammation could be verified in children with OSA, since these patients had elevated serum concentration of hsCRP. It is already confirmed in adults (28) and in children (29), that OSA is associated with elevated levels of CRP and that the severity of OSA is proportional to the plasma CRP concentration. Hypoxia and sleep disturbances in patients with OSA may contribute to elevated CRP in their serum (28). Taken together, these results suggest that there is a relationship between hypoxemic stress in patients with OSA and systemic inflammation, confirmed by elevated CRP values. The concentrations of CRP detected in patients with OSA are comparable to the values associated with healthy individuals at risk for future cardiovascular disease (30).

Now, it is possible to determine direct markers of local inflammation, i.e. FENO, and indirect marker of latent systemic inflammation in serum, i.e. hsCRP. The present study indicated that urates in EBC (but not in serum) may be used as a marker of local synthesis of antioxidant compunds, but definitive conclusion must be supported by investigations involving larger number of participants.

\section{References}

1. Young T, Peppard P, Gottlieb J. Epidemiology of obstructive sleep apnea, a population health perspective. Am J Respir Crit Care Med 2002;165:1217-39.

2. Marcus CL. Sleep-disordered breathing in children. Am J Respir Crit Care Med 2001;164:16-30.

3. Katz ES, D'Ambrosio CM. Pediatric obstructive sleep apnea syndrome. Clin Chest Med 2010;31:221-34.

4. Granzotto EH, Aquino FV, Flores JA, Neto JF. Tonsil size as a predictor of cardiac complications in children with sleepdisordered breathing. Laryngoscope 2010;120:1246-51.

5. Levy P, Pépin J-L, Amaud C, Tamisier R, Borel J-C, Dematteits $M$, et al. Intermitteent hypoxia and sleep-disordered breathing: current concept and perspectives. Eur Respir J 2008;32:1082-95.

6. Glantzounis GK, Tsimoyiannis EC, Kappas AM, Galaris DA. Uric acid and oxidative stress. Curr Pharm Des 2005;11:4145-51.

7. Powers SK, Jackson MJ. Exercise-induced oxidative stress: Cellular mechanisms and impact on muscle force production. Physiol Rev 2008;88:1243-76.

8. Sevanian A, Davies KJ, Hochstein P. Serum urate as an antioxidant for ascorbic acid. Am J Clin Nutrition 1991;54:1129S34 .
We are aware of our study limitations such as small (cross-sectional) study sample, especially in the control group of children, and the lack of control group of similar BMI as in OSA patients. In addition, the findings could be more appealing if some other biomarker of oxidative stress, i.e. 8-isoprostane, had been measured.

Based on the results of this preliminary study, we consider that further investigations should be done to identify the exact anatomical site of origin of urates in patients with OSA, and to explain the relationship between urates with other biomarkers of oxidative stress.

\section{Acknowledgment}

The results presented were obtained in the scope of a scientific project 277-2770966-0965, entitled Exhaled Breath Condensate as a Source of Lung Disease Biomarkers in Children, carried out with support from the Ministry of Science, Education and Sports of the Republic of Croatia.

Potential Conflicts of Interest: None declared.

9. Muraoka S, Miura T. Inhibition by uric acid of free radicals that damage biological molecules. Pharmacol Toxicol 2003;93:284-9.

10. Standards and indications for cardiopulmonary sleep studies in children. American Thoracic Society. Am J Respir Crit Care Med 1996;153:866-78.

11. Horvath I, Hunt J, Barnes PJ. On behalf of the ATS/ERS Task Force on Exhaled Breath Condensate. Exhaled breath condensate: methodological recommendations and unresolved questions. Eur Respir J 2005;26:523-48.

12. Marusteri $M$, Bacarea V. Comparing groups for statistical differences: how to choose the right statistical test? Biochem Med 2010;20:15-32.

13. Marcus CL, Omlin KJ, Basinki DJ, Bailey $S L$, Rachal $A B$, Von Pechmann WS, et al. Normal polysomnographic values for children and adolescents. Am Rev Respir Dis 1992;146:1235-9.

14. Galez D, Dodig S, Raos M, Nogalo B. C-reactive protein in children with asthma and allergic rhinitis. Biochem Med 2006;16:163-9.

15. Galez D, Dodig S, Raos M, Nogalo B. C-reactive protein and complement components $\mathrm{C} 3$ and $\mathrm{C} 4$ in children with latent tuberculosis infection Biochem Med 2008;18:52-8. 
16. Van $\operatorname{der}$ Vliet $A, O^{\prime}$ Neill $C A$, Cross $C E$, Koostra JM, Volz WG, Halliwell $B$, et al. Determination of low-molecular-mass antioxidant concentrations in human respiratory tract lining fluids. Am J Physiol 1999;276:L289-96.

17. Effros RM. Exhaled breath condensates and COPD. Eur Respir J 2009;33:1238.

18. Panus PC, Burgess B, Freeman BA. Characterisation of cultured alveolar epithelial cell xanthine dehydrogenase/oxidase. Biochem Biophys Acta 1991;1091:303-9.

19. Dodig S, Čepelak I, Vlašić Ž, Zrinski Topić R, Banović S. Urates in exhaled breath condensate of children with asthma. LabMedicine 2010;47:728-39.

20. Mudway IS, Blomberg A, Frew AJ, Holgate ST, Sandsröm T, Kelly FJ. Antioxidant consumption and repletion kinetics in nasal lavage fluid following exposure of healthy human volunteers to ozone. Eur Respir J 1999;13:1429-38.

21. Kelly FJ, Blomberg A, Frew A, Holgate ST, Sandström T. Antioxidant kinetics in lung lavage fluid following exposure of humans to nitrogen dioxide. Am J Respir Crit Care Med 1996;154:1700-5.

22. Goldbart AD, Krishna J, Li RC, Serpero LD, Gozal D. Inflammatory mediators in exhaled breath condensate of children with obstructive sleep apnea syndrome. Chest 2006;130;143-8.
23. Li Y, Chongsuvivatwong V, Geater A, Liu A. Exhaled breath condensate cytokine level as a diagnostic tool for obstructive sleep apnea syndrome. Sleep Med 2009;10:95-103.

24. Cepelak I, Dodig S. Exhaled breath condensate: a new method for lung disease diagnosis. Clin Chem Lab Med 2007;45:945-52.

25. Petrosyan $M$, Perraki E, Simoes D, Koutsourelakis I, Vagiakis $E$, Roussos C, et al. Exhaled breath markers in patients with obstructive sleep apnoea. Sleep Breath 2008;12:207-15.

26. Biltagi MA, Maguid MA, Ghafar MA, Farid E. Correlation of 8-isoprostane, interleukin-6 and cardiac functions with clinical score in childhood obstructive sleep apnoea. Acta Paediatr (Norway) 2008;97:1397-405.

27. Navratil M, Plavec D, Dodig S, Jelčić Ž, Nogalo B, Erceg D, et al. Markers of systemic and lung inflammation in childhood asthma. J Asthma 2009;46:822-8.

28. Shamsuzzaman AS, WinnickiM, Lanfranchi P, WolkR, KaraT, Accurso $V$, et al. Elevated C-reactive protein in patients with obstructive sleep apnea. Circulation 2002;105:2462-4.

29. Tauman R, Ivanenko A, O'Brien LM, Gozal D. Plasma C-reactive protein levels among children with sleep-disordered breathing. Pediatrics 2004;113:564-9.

30. Ridker PM. High-sensitivity C-reactive protein: potential adjunct for global risk assessment in the primary prevention of cardiovascular disease. Circulation 2001;103:1813-8.

\section{Koncentracija urata u kondenzatu izdaha kod djece s opstruktivnom apnejom u spavanju}

\section{Sažetak}

Uvod: Koncentracija urata bi mogla biti biljeg oksidacijskog stresa. Cilj ovog istraživanja bio je provjeriti postoji li razlika u koncentraciji urata u kondenzatu izdaha (engl. exhaled breath condensate, EBC) kod djece oboljele od opstruktivne apneje u spavanju (engl. obstructive sleep apnea, OSA) i zdrave djece.

Materijali i metode: EBC je dobiven od djece oboljele od OSA i klinički zdrave djece. Mjerenja koncentracije urata u EBC i serumu bila su provedena enzimskim kolorimetrijskim testom.

Rezultati: Viša koncentracija urata u EBC kod djece s OSA nego u skupini zdrave djece ukazuje na oksidacijski stres u njihovim dišnim putovima. Budući da nije bilo značajne razlike u koncentracijama urata u serumu između skupine djece oboljele od OSA i zdrave djece, može se zaključiti da se urati sintetiziraju u dišnim putovima djece s OSA.

Zaključak: Ovo istraživanje ukazuje da se urati u EBC (ali ne i u serumu) mogu rabiti i kao biljezi lokalne sinteze antioksidacijskih spojeva, no konačan zaključak mora biti donesen nakon daljnjih istraživanja na većem broju ispitanika.

Ključne riječi: kondenzat izdaha; opstruktivna apneja u spavanju; oksidacijski stres; urati 